\title{
R497K polymorphism in epidermal growth factor receptor gene is associated with the risk of acute coronary syndrome Lin-Bo Gao ${ }^{\dagger 1}$, Bin Zhou ${ }^{\dagger 2}$, Lin Zhang ${ }^{2}$, Ye-Sheng Wei ${ }^{3}$, Yan-Yun Wang1, Wei- Bo Liang1, Mei-Li Lv³, Xin-Min Pan ${ }^{4}$, Yu-Cheng Chen ${ }^{5}$ and Li Rao*5
}

\begin{abstract}
Address: ${ }^{1}$ Department of Forensic Biology, West China School of Preclinical and Forensic Medicine, Sichuan University, Chengdu 610041, Sichuan, PR China, ${ }^{2}$ Laboratory of Molecular Translational Medicine, West China Second University Hospital, Sichuan University, Chengdu 610041, Sichuan, PR China, ${ }^{3}$ Department of Immunology, West China School of Preclinical and Forensic Medicine, Sichuan University, Chengdu 610041, Sichuan, PR China, ${ }^{4}$ Department of Forensic Pathology, West China School of Preclinical and Forensic Medicine, Sichuan University, Chengdu 610041, Sichuan, PR China and ${ }^{5}$ Department of Cardiology, West China Hospital of Sichuan University, Chengdu 610041, Sichuan, PR China

Email: Lin-Bo Gao - phdkow@yahoo.com.cn; Bin Zhou - zb630@163.com; Lin Zhang - zhanglin@scu.edu.cn; YeSheng Wei - wysh22@163.com; Yan-Yun Wang - wyanyun@gmail.com; Wei-Bo Liang - liangweibo@gmail.com; MeiLi Lv - meililv780900@126.com; Xin-Min Pan - phagocytosis@126.com; Yu-Cheng Chen - chenyucheng2003@126.com; Li Rao* - lrlz1989@yahoo.com.cn

* Corresponding author †Equal contributors
\end{abstract}

Published: 30 July 2008

BMC Medical Genetics 2008, 9:74 doi:10.1 186/147/-2350-9-74
Received: 3 March 2008

Accepted: 30 July 2008

This article is available from: http://www.biomedcentral.com/I47/-2350/9/74

(C) $2008 \mathrm{Gao}$ et al; licensee BioMed Central Ltd.

This is an Open Access article distributed under the terms of the Creative Commons Attribution License (http://creativecommons.org/licenses/by/2.0), which permits unrestricted use, distribution, and reproduction in any medium, provided the original work is properly cited.

\begin{abstract}
Background: Previous studies suggested that genetic polymorphisms in the epidermal growth factor receptor (EGFR) gene had been implicated in the susceptibility to some tumors and inflammatory diseases. EGFR has been recently implicated in vascular pathophysiological processes associated with excessive remodeling and atherosclerosis. Acute coronary syndrome (ACS) is a clinical manifestation of preceding atherosclerosis. Our purpose was to investigate the association of the EGFR polymorphism with the risk of ACS. In this context, we analyzed the HER-I R497K and EGFR intron I (CA $)_{n}$ repeat polymorphisms in 191 patients with ACS and 210 age- and sexmatched controls in a Chinese population, using a polymerase chain reaction-restriction fragment length polymorphism (PCR-RFLP) strategy and direct sequencing.
\end{abstract}

Results: There were significant differences in the genotype and allele distribution of R497K polymorphism of the EGFR gene between cases and controls. The Lys allele had a significantly increased risk of ACS compared with the Arg allele (adjusted OR $=1.49,95 \% \mathrm{Cl}$ : I.12-1.98, adjusted $P=0.006)$. However, no significant relationship between the number of $(C A)_{n}$ repeats of EGFR intron I (both alleles $<20$ or any allele $\geq 20$ ) and the risk of ACS was observed (adjusted $\mathrm{OR}=0.97,95 \% \mathrm{Cl}: 0.58-1.64$, adjusted $P=0.9 \mathrm{II}$ ). Considering these two polymorphisms together, there was no statistically significant difference between the two groups.

Conclusion: R497K polymorphism of the EGFR gene is significantly associated with the risk of ACS. Our data suggests that R497K polymorphism may be used as a genetic susceptibility marker of the ACS. 


\section{Background}

Acute coronary syndrome (ACS) is a clinical manifestation of preceding atherosclerosis, inflammation and thrombosis [1]. It constitutes an important cause of mortality and morbidity in many countries including China. Although the exact mechanism of ACS pathogenesis is not fully known, many factors such as age, gender, smoking, hypertension, diabetes mellitus, hypercholesterolemia, obesity and sedentary lifestyle are involved in the disease [2-4]. In addition, several studies have shown that genetic factors such as single nucleotide polymorphisms (SNPs) of angiotensin converting enzyme (ACE), platelet glycoprotein IIb HPA-3, and matrix metalloproteinase-3 (MMP-3) also play a crucial role in the development of ACS [5-7]. Despite many gene SNPs [5-14] have been reported to be associated with ACS, it is necessary to discover novel gene variants in the risk of ACS. Firstly, ACS is a disease related to multiple genes. Secondly, the molecular mechanism of ACS is unclear, and it may be benefit to elucidate the pathogenesis of ACS by finding novel gene variants.

The epidermal growth factor receptor (EGFR) is a transmembrane glycoprotein of $170 \mathrm{kDa}$ (1186 amino acids) encoded by a gene located in the short arm of chromosome 7 (chromosome 7p12.1-12.3) [15]. And it contains 26 exons [16]. A polymorphic variant of the EGFR arising from a single nucleotide change $(\mathrm{G} \rightarrow \mathrm{A})$ leading to an arginine (Arg) $\rightarrow$ Lysine (Lys) substitution in codon 497 (HER-1 R497K) in the extracellular domain within subdomain IV of the EGFR gene has been identified [17]. It is one of the key polymorphisms within the EGFR signaling pathway. An in vitro study has shown that the variant HER-1 497K has attenuated functions in ligand binding, growth stimulation, tyrosine kinase activation, and induction of protooncogenes myc, fos, and jun compared with the "wild-type" HER-1 497R [18]. Another polymorphic variant of the EGFR is a highly polymorphic region in intron 1 of the EGFR gene which is associated with transcription levels of EGFR in vitro and in vivo $[19,20]$. The length of this $(\mathrm{CA})_{\mathrm{n}}$ dinucleotide polymorphism correlates inversely with the transcriptional activity of the gene. In vitro studies have shown that the transcriptional activity in cell lines containing a prolonged polymorphic region (>20 CA repeats) was markedly reduced compared with cells containing a shorter allele (16 repeats). Recently, several studies reported that genetic polymorphisms of the EGFR gene had been implicated in the risk of a range of tumors [21-26]. In addition to its prominent role in the development of several cancers [27], EGFR has been currently implicated in vascular pathophysiological processes associated with excessive remodeling and atherosclerosis $[28,29]$. Moreover, EGFR has been identified on intimal smooth muscle cells within human atherosclerotic plaque and cultured rat aortic smooth muscle cells, which mediates cell proliferation and DNA synthesis [30-32]. Atherosclerosis, regarded as a chronic inflammatory process [33], plays a fundamental role in the pathogenesis of ACS.

Therefore, we hypothesized that HER-1 R497K and EGFR intron $1(\mathrm{CA})_{\mathrm{n}}$ repeat polymorphisms may modulate the susceptibility to ACS. To test this hypothesis, we conducted a hospital-based case-control study to evaluate the potential association between HER-1 R497K and intron 1 $(\mathrm{CA})_{\mathrm{n}}$ repeat polymorphisms in the EGFR gene and the risk of ACS in a Chinese population.

\section{Results}

\section{Characteristics of the study population}

The demographics of the cases and controls enrolled in this study are shown in Table 1 . There were no significant differences between the cases and controls for the age, gender distribution and body mass index. However, the smoking status, total cholesterol, LDL-cholesterol and triglycerides were significantly higher in the ACS group than in the control group $(P<0.001)$, whereas HDL-cholesterol was significantly lower in the ACS group than in the control $\operatorname{group}(P<0.001)$. Hypertension, diabetes mellitus and coronary stenosis were observed only in patients with ACS.

\section{HER-I R497K polymorphism}

The genotype and allele frequencies of the HER-1 R497K polymorphism between the controls and the cases are shown in Table 2. And the genotype distributions were in Hardy-Weinberg's equilibrium. There were significant differences in the genotype and allele frequency of the HER1 R497K polymorphism between ACS and control groups. Compared with the Arg allele, the frequency of the $L y s$ allele was significantly higher in the patient group than in the control group (adjusted OR $=1.49,95 \%$ CI: $1.12-$ 1.98 , adjusted $P=0.006$ ).

\section{EGFR intron I (CA)n repeat polymorphism}

In 420 chromosomes from 210 controls, 10 alleles with 14-23 CA repeats were found (Table 3). The allele distribution in healthy Chinese individuals, ranging from $0.5 \%$ to $42.9 \%$ with a predominance of 16 and 20 repeats, was in agreement with that of Asian populations reported in a previous study [34]. The allele distribution in ACS patients was similar to the control group except that a novel (CA) repeat length of $\mathrm{n}=13$ was determined in one patient. No significant difference was observed in the distribution of genotype and allele between cases and controls.

To evaluate the effect of the number of $(\mathrm{CA})_{\mathrm{n}}$ repeats on patients with ACS and controls, we separated the genotypes into two subgroups: both $(\mathrm{CA})_{\mathrm{n}}$ repeats $<20$ and 
Table I: The characteristics of the study population

\begin{tabular}{|c|c|c|c|}
\hline & Control & ACS & $\mathrm{Pa}$ \\
\hline & $n=210(\%)$ & $\mathrm{n}=191(\%)$ & \\
\hline $\operatorname{Sex}(M / F)$ & $132 / 78(62.9 / 37.1)$ & I I 2/79 (58.6/4I.4) & NS \\
\hline Age (years; mean $\pm S D)$ & $59.4 \pm 11.2$ & $60.6 \pm 10.9$ & NS \\
\hline Body mass index $\left(\mathrm{kg} / \mathrm{m}^{2} ;\right.$ mean $\left.\pm \mathrm{SD}\right)$ & $25.2 \pm 3.3$ & $26.6 \pm 4.2$ & NS \\
\hline UA/NSTEMI/STEMI & & $102 / 49 / 40(53.4 / 25.7 / 20.9)$ & \\
\hline $\begin{array}{l}\text { Smoking status } \\
\text { (never/former/current) }\end{array}$ & $\begin{array}{l}111 / 53 / 46 \\
(52.9 / 25.2 / 21.9)\end{array}$ & $\begin{array}{l}62 / 73 / 56 \\
(32.5 / 38.2 / 29.3)\end{array}$ & $<0.001$ \\
\hline Total cholesterol $(\mathrm{mmol} / \mathrm{l} ;$ mean $\pm \mathrm{SD})$ & $3.57 \pm 0.93$ & $5.24 \pm 1.19$ & $<0.001$ \\
\hline HDL-cholesterol (mmol//;mean \pm SD) & $1.15 \pm 0.40$ & $1.02 \pm 0.42$ & $<0.001$ \\
\hline LDL-cholesterol (mmol/l; mean \pm SD) & $2.21 \pm 0.69$ & $3.04 \pm 0.99$ & $<0.001$ \\
\hline Triglycerides (mmol/l; mean \pm SD) & $1.27 \pm 0.55$ & $1.92 \pm 0.90$ & $<0.001$ \\
\hline Hypertension & & $85(44.5)$ & \\
\hline Diabetes mellitus & & $38(19.9)$ & \\
\hline \multicolumn{4}{|l|}{ Number of stenosis vessels } \\
\hline I & & $88(46.1)$ & \\
\hline 2 & & $75(39.3)$ & \\
\hline 3 & & $28(14.7)$ & \\
\hline
\end{tabular}

ACS, acute coronary syndrome; UA, unstable angina; NSTEMI, non-ST-segment elevation myocardial infarction; STEMI, ST-segment elevation myocardial infarction; NS, not significant

${ }^{a}$ ACS vs. controls by Student's t-test or Chi-squared test.

any $(C A)_{n}$ repeats $\geq 20$. No significant relationship between the number of $(\mathrm{CA})_{\mathrm{n}}$ repeats of EGFR intron 1 and the risk of ACS was observed (adjusted OR $=0.97$, 95\% CI: $0.58-1.64$, adjusted $P=0.911$ ) (Table 2).

\section{Combined analysis and linkage disequilibrium}

When we considered these two polymorphisms together, there was no statistically significant difference between patients with ACS and controls (data not shown).

No statistically significant evidence for linkage disequilibrium between the HER-1 R497K polymorphism and EGFR $(\mathrm{CA})_{\mathrm{n}}$ repeat polymorphism was found in our study (data not shown).

\section{Stratified analysis}

When the analyses were stratified by hypertension and diabetes mellitus, no significant association was observed between the R497K polymorphism and the risk of ACS (data not shown).

\section{Multivariable logistic regression analysis}

This analysis showed that independent risk factors for ACS were cigarette smoking, total cholesterol, LDL-cholesterol, triglycerides, and R497K (Table 4).

\section{Discussion}

In this retrospective, hospital-based case-control study, we found that the frequency of Lys allele in the ACS group was significantly higher than that in control. Additionally, multivariable logistic regression analysis showed that

Table 2: The genotype and allele distribution of EGFR polymorphisms in ACS patients and controls

\begin{tabular}{|c|c|c|c|c|c|}
\hline Polymorphism & $\begin{array}{l}\text { Control } \\
n=210(\%)\end{array}$ & $\begin{array}{l}\text { ACS } \\
n=191(\%)\end{array}$ & $\begin{array}{l}\text { Crude OR } \\
(95 \% \mathrm{Cl})\end{array}$ & $\begin{array}{l}\text { Adjusted ORa } \\
(95 \% \mathrm{Cl})\end{array}$ & $\begin{array}{c}\text { Adjusted } \\
\mathrm{Pa}\end{array}$ \\
\hline \multicolumn{6}{|l|}{ R497K } \\
\hline \multicolumn{6}{|l|}{ genotypes } \\
\hline Arg/Arg & $45(21.4)$ & $32(16.8)$ & 1.00 (Ref) & 1.00 (Ref) & 1.00 (Ref) \\
\hline Arg/Lys & $107(51.0)$ & $79(4 I .4)$ & $\mathrm{I} .04(0.6 \mathrm{I}-\mathrm{I} .78)$ & $1.07(0.62-1.85)$ & 0.807 \\
\hline Lys/Lys & $58(27.6)$ & $80(41.9)$ & $1.94(1.10-3.41)$ & $1.98(1.12-3.49)$ & 0.018 \\
\hline \multicolumn{6}{|l|}{ alleles } \\
\hline Arg allele frequency & 197 (46.9) & 143 (37.4) & 1.00 (Ref) & 1.00 (Ref) & 1.00 (Ref) \\
\hline Lys allele frequency & $223(53.1)$ & $239(62.6)$ & $1.48(1.11-1.96)$ & $1.49(1.12-1.98)$ & 0.006 \\
\hline \multicolumn{6}{|l|}{$(C A)_{n}$ repeats } \\
\hline Both $(C A)_{n}$ repeats $<20$ & $35(16.7)$ & $33(17.3)$ & I.00 (Ref) & 1.00 (Ref) & 1.00 (Ref) \\
\hline Any $(C A)_{n}$ repeats $\geq 20$ & $175(83.3)$ & $158(82.7)$ & $0.96(0.57-1.6 I)$ & $0.97(0.58-1.64)$ & 0.911 \\
\hline
\end{tabular}

a adjusted for sex and age by the logistic regression model. 
Table 3: The allele distribution of EGFR intron I (CA $)_{n}$ repeat in ACS patients and controls

\begin{tabular}{cccccc}
\hline & \multicolumn{2}{c}{ Control $(\mathrm{n}=210)$} & & \multicolumn{2}{c}{ ACS $(\mathrm{n}=191)$} \\
\cline { 2 - 5 } \cline { 5 - 5 } & $\mathrm{n}$ & $\% \mathrm{a}$ & & $\mathrm{n}$ & $\%^{\mathrm{a}}$ \\
\hline 13 & 0 & 0.0 & & $\mathrm{I}$ & 0.3 \\
14 & 2 & 0.5 & & 3 & 0.8 \\
15 & 23 & 5.5 & & 16 & 4.2 \\
16 & 66 & 15.7 & & 69 & 18.1 \\
17 & 28 & 6.7 & & 24 & 6.3 \\
18 & 13 & 3.1 & & 5 & 1.3 \\
19 & 55 & 13.1 & & 39 & 10.2 \\
20 & 180 & 42.9 & & 172 & 45.0 \\
21 & 38 & 9.0 & & 31 & 8.1 \\
22 & 12 & 2.9 & & 21 & 5.5 \\
23 & 3 & 0.7 & & 1 & 0.3 \\
\hline
\end{tabular}

aDoes not add up to $100.0 \%$ because of rounding.

R497K was an independent risk factor for ACS besides some classical risk factors, such as smoking status, total cholesterol, LDL-cholesterol, and triglycerides. It indicates that $L y s$ allele may be a risk factor for ACS in a Chinese population. This finding is in consistent with our hypothesis and suggests that the R497K polymorphism may be used as a genetic susceptibility marker of the ACS.

For the (CA)n repeat in intron 1 of EGFR polymorphism, alleles $20(42.9 \%)$ and $16(15.7 \%)$ were the two most common in a Chinese population in our current study, which was similar to that reported by Liu et al. [34] in a U.S. Asian population (62.9\% for allele 20 and $17.4 \%$ for allele 16). However, the allelic distribution was reversed in Caucasians and African-Americans, with allele 16 the most common ( $43.2 \%$ and $41.7 \%$, respectively), followed by allele 20 at a much lower frequency $(21.0 \%$ and $14.3 \%$, respectively). It suggests that the allelic frequencies of the EGFR intron 1 polymorphism might vary among different ethnic groups.

The EGFR, also known as HER-1 or erbB-1, is a member of the human epithelial receptor tyrosine kinase family. The EGFR gene is located on chromosome 7 [15] and contains 26 exons [16]. Exons 1 to 14 code for the extracellular

Table 4: Results of multivariable logistic regression analysis: final significant variables in equation

\begin{tabular}{llll}
\hline Variable & Odds ratio & $95 \% \mathrm{Cl}$ & $P$ \\
\hline Smoker & 2.63 & $1.23-5.63$ & 0.013 \\
Total cholesterol & 7.29 & $4.60-11.56$ & $<0.001$ \\
LDL-cholesterol & 13.75 & $6.77-27.93$ & $<0.001$ \\
Triglycerides & 6.40 & $3.46-11.86$ & $<0.001$ \\
R497K & 1.72 & $1.03-2.86$ & 0.039 \\
\hline
\end{tabular}

domain. Exon 15 codes for the transmembrane domain, and exons 16 to 26 code for the intracellular domain [35]. Transcription of the EGFR gene is regulated by two enhancer elements. The first is located upstream near the transcription initiation site and the second downstream in intron 1 [36]. The latter contains a characteristic simple sequence repeat (SSR) of CA dinucleotides, the length of which exhibits interethnic differences [34]. In addition, the length of this polymorphism has been observed to correlate inversely with EGFR transcription in both in vitro experiments and breast cancer specimens. The longer allele with 21 repeats was shown an $80 \%$ reduction of gene expression compared with the shorter allele with 16 repeats $[19,20]$. In this present study, no significant difference was observed in EGFR intron 1 (CA) $)_{n}$ repeat polymorphism between cases and controls. When taking HER1 R497K and EGFR intron 1 (CA) $)_{n}$ repeat polymorphisms into together, there was no statistically significant difference between patients with ACS and controls as well.

Currently, EGFR is considered as a convergence point in the complex signaling network and regulation of cellular functions, such as cell growth, differentiation, motility, survival and death [37-39]. Thereby, it plays a crucial role in various pathophysiological processes, including atherosclerosis. EGFR has been demonstrated on both intimal smooth muscle cells within human atherosclerotic plaque and cultured rat aortic smooth muscle cells [30-32]. Furthermore, it has previously reported that EGFR is present on rabbit peripheral blood leucocytes, and co-localises with macrophages within lesions of atherosclerosis in the cholesterol-fed rabbit [40], which mediates both chemotactic responses towards monocytes and mitogenic responses towards monocyte-derived macrophages in vitro. Transactivation of the EGFR mediates endothelin-1 (a powerful vasoconstrictor, involving in vasospastic diseases such as coronary artery disease) signaling in vascular smooth muscle cells and isolated arteries [41]. This identification heightens the potential importance of EGFR in atherogenesis and other inflammatory disease. A few studies have shown that polymorphism of EGFR was associated with susceptibility of some inflammatory diseases [42,43]. For example, Wang et al. [42] reported that asthmatic patients had a significantly higher incidence of having shorter alleles ( $\leq 16$ CA repeats) compared with control subjects $(P<0.05)$. Martin et al. [43] reported that the frequency of the WT $(\mathrm{Arg})$ allele at position R497K in the EGFR gene was significantly higher in ulcerative colitis than in controls $(P=0.04)$.

However, no previous study has shown the relationship between HER-1 R497K and EGFR intron $1(\mathrm{CA})_{\mathrm{n}}$ repeat polymorphisms and patients with ACS. To our knowledge, the present pilot study is the first to investigate the association between them. We found that R497K but not 
$(\mathrm{CA})_{\mathrm{n}}$ repeat polymorphism might be used as a genetic susceptibility marker of the ACS. The exact mechanism by which the Lys allele may be associated with the risk of ACS is unclear. In 1993, a variant EGFR of an arginine to lysine substitution at codon 497 was identified [17]. Wild-type EGFR (Arg allele) differs from mutant EGFR (Lys allele) with respect to epithelial proliferation following the administration of EGF and TGF- $\alpha$ in rodents [18]. Thus, it is possible that mutations which influence the function or expression of EGFR (such as attenuating its ligand binding as well as subsequent activation of its downstream effectors) might predispose to the development of ACS.

\section{Conclusion}

To conclude, in the present retrospective study, we found that HER-1 R497K polymorphism was significantly associated with the risk of ACS in a Chinese population. These results suggested that genetic polymorphism of EGFR (arginine $\rightarrow$ Lysine mutation) might be clinically important in the development and progression of ACS. Nevertheless, there are some limitations in our study, and several questions still should be addressed. For instance, the molecular mechanism by which the EGFR gene polymorphisms are associated with ACS is unknown. It should also be emphasized that other polymorphisms in linkage disequilibrium with the $\mathrm{R} 497 \mathrm{~K}$ and $(\mathrm{CA})_{\mathrm{n}}$ repeat may also contribute to variability in EGFR expression. In addition, the inadequate study design such as non-random sampling and a limited sample size should also be considered. Therefore, One needs to explore further, whether EGFR polymorphisms are an independent risk factor or an indirect marker of different genetic and environmental factors. Further studies are required to evaluate haplotype, relationship among genotypes, and the molecular mechanisms by which EGFR is involved in susceptibility to ACS in diverse ethnic populations and larger number of patients.

\section{Methods}

\section{Study population}

The case-control population consisted of 401 adult unrelated Chinese who were selected from the same population living in China (Table 1). A total of 191 ACS patients (112 males and 79 females, mean age: $60.6 \pm 10.9$ ), including 102 of whom suffering from unstable angina (UA), 49 from non-ST-segment elevation myocardial infarction (NSTEMI) and 40 from ST-segment elevation myocardial infarction (STEMI), were recruited from West China hospital, Sichuan University between July 2005 and January 2007. The diagnosis of ACS was performed according to the definitions proposed by the European Society of Cardiology and the American College of Cardiology [44]. Exclusion criteria were evidence of significant concomitant diseases, in particular, hemodynamic valvu- lar heart disease, known cardiomyopathy and malignant diseases, as well as a febrile condition.

The control group included 210 healthy volunteers $(132$ males and 78 females, mean age: $59.4 \pm 11.2$ ) who visited the general health check-up division at West China Hospital, Sichuan University. Selection criteria for controls were no history of heart disease or systemic disease and found to be normal by physical examination, electrocardiogram, and echocardiogram. There was no significant difference between patients and control subjects in terms of gender and age distribution. Written informed consent was obtained from all the subjects, and the study was performed with the approval of the ethics committee of Chinese Human Genome.

\section{Plasma lipid determination}

The method was described in our previous study [45]. In brief, venous blood sample was drawn after an overnight fast. Serum cholesterol, HDL-cholesterol, LDL-cholesterol and triglycerides were measured by automated enzymatic methods. All blood lipid samples were examined at Olympus-1000 automated analyzer (Japan).

\section{DNA extraction and EGFR genotyping}

Genomic DNA was extracted from peripheral blood with an extraction kit (Bioteke Corporation; Beijing, China) according to the manufacturer's instructions. R497K in exon 13 genotype was determined by using a PCR-RFLP assay and DNA sequencing analysis. The PCR primers were 5'-TGCTGTGACCCACTCTGTCT-3' (forward) and 5'CCAGAAGGTTGCACTTGTCC-3' (reverse). The PCR reactions were performed in a total volume of $25 \mu \mathrm{l}$ containing $100 \mathrm{ng}$ genomic DNA, $20 \mathrm{pM}$ of each primer, $0.2 \mathrm{mM}$ dNTPs, $20 \mathrm{mM}$ Tris- $\mathrm{HCl}(\mathrm{pH} \mathrm{8.8)}, 10 \mathrm{mM} \mathrm{KCl}, 10 \mathrm{Mm}$ $(\mathrm{NH} 4)_{2} \mathrm{SO}_{4}, 2 \mathrm{mM} \mathrm{MgSO}_{4}, 0.1 \%$ Triton X-100, and 1 unit of Taq polymerase (New England BioLabs). The PCR cycle conditions consisted of an initial denaturation step at $94^{\circ} \mathrm{C}$ for 5 min followed by 34 cycles of $30 \mathrm{~s}$ at $94^{\circ} \mathrm{C} ; 45$ s at $60^{\circ} \mathrm{C}$ and $45 \mathrm{~s}$ at $72^{\circ} \mathrm{C}$; and a final elongation at $72^{\circ} \mathrm{C}$ for $10 \mathrm{~min}$. After PCR amplification, the PCR products were digested at $37^{\circ} \mathrm{C}$ overnight with the restriction enzyme Mva I (Fermentas). The digested PCR products, including a single fragment of $155 \mathrm{bp}$ (uncuttable by restriction enzyme) and two fragments of $88 \mathrm{bp}$ and $67 \mathrm{bp}$ (cuttable), were resolved on 2\% agarose gel and 8\% acrylamide gel respectively, and stained with ethidium bromide for visualization under UV light.

The $(\mathrm{CA})_{\mathrm{n}}$ repeat polymorphism in intron 1 of the EGFR gene was genotyped by direct-sequencing. The primers were 5'-TTCTCCTCAAAACCCGGAGAC-3' (forward) and 5'-GTCACGAAGCCAGACTCGCT-3' (reverse). PCR conditions were as follows: initial denaturation at $94^{\circ} \mathrm{C}$ for 5 min; 30 cycles of denaturation at $94^{\circ} \mathrm{C}$ for $30 \mathrm{~s}$, annealing 
at $60^{\circ} \mathrm{C}$ for $30 \mathrm{~s}$, extension at $72^{\circ} \mathrm{C}$ for $30 \mathrm{~s}$, and final extension of $72^{\circ} \mathrm{C}$ for $10 \mathrm{~min}$. After PCR amplification, the exact number of the $(\mathrm{CA})_{\mathrm{n}}$ repeat was confirmed by direct sequencing.

\section{Statistical analysis}

In this exploratory, retrospective study, genotype, allele frequencies and stratified analysis of EGFR were compared between ACS cases and controls using the $\chi^{2}$ test and Fisher's exact test when appropriate. The association between R497K polymorphism and risk of ACS was estimated by computing the ORs and their 95\% CIs using logistic regression analyses for crude ORs, adjusted ORs and adjusted $P$ value when adjusted for sex and age. Demographic and clinical data between groups were compared by $\chi^{2}$ test or Student's t-test. Hardy-Weinberg equilibrium was tested for with a goodness of fit $\chi^{2}$-test with one degree of freedom to compare the observed genotype frequencies among the subjects with the expected genotype frequencies. Multivariable logistic regression analysis was performed on the effect of the EGFR polymorphism and other risk factors for ACS. Statistical significance was assumed at the $P<0.05$ level. The SPSS statistical software package version 11.5 was used for all of the statistical analysis.

\section{Authors' contributions}

L-BG, BZ and LR conceived of the study, participated in its design, carried out most of the experiments and drafted the manuscript. LZ and Y-SW participated in design of study and helped to draft the manuscript. Y-YW performed DNA extraction. W-BL and M-LL participated in genotyping. X-MP and Y-CC participated in plasma lipid determination. All authors have read and approved the final manuscript.

\section{Acknowledgements}

This study was supported by the National Natural Science Foundation of China (No. 30570717). This work was supported by a grant from the Applied Basic Research Programs of Science and Technology Commission Foundation of Sichuan Province (No. 04JY029-078-I).

\section{References}

I. Hansson GK: Inflammation, atherosclerosis, and coronary artery disease. N Engl J Med 2005, 352: I685-95.

2. Anderson KM, Wilson PW, Odell PM, Kannel WB: An updated coronary risk profile. A statement for health professionals. Circulation 1991, 83:356-62.

3. Kannel WB: Lipids, diabetes, and coronary heart disease: insights from the Framingham Study. Am Heart J 1985, I I 0: I 1 00-7.

4. Yano K, Reed DM, McGee DL: Ten-year incidence of coronary heart disease in the Honolulu Heart Program. Relationship to biologic and lifestyle characteristics. Am J Epidemiol 1984, I 1 9:653-66.

5. Méthot J, Hamelin BA, Bogaty P, Arsenault M, Plante S, Poirier P: ACE-DD genotype is associated with the occurrence of acute coronary syndrome in postmenopausal women. Int J Cardiol 2005, 105:308-14.

6. Lekakis J, Bisti S, Tsougos E, Papathanassiou A, Dagres N, Ikonomidis I, Soteriadou E, Tselepis AD, Goudevenos J, Kremastinos DT: Plate- let glycoprotein Ilb HPA-3 polymorphism and acute coronary syndromes. Int J Cardiol 2007 in press.

7. Liu PY, Li YH, Chan SH, Lin LJ, Wu HL, Shi GY, Chen JH: Genotypephenotype association of matrix metalloproteinase-3 polymorphism and its synergistic effect with smoking on the occurrence of acute coronary syndrome. Am J Cardiol 2006, 98:1012-7.

8. Ji XW, Zhang AY, Guan LX: [Association between angiotensinconverting enzyme and endothelial nitric oxide synthase gene polymorphism and risk of coronary artery disease]. Zhonghua Xin Xue Guan Bing Za Zhi 2007, 35: 1024-8.

9. Qiudi Ji, Tong Yang, Wenyu Li: [Analysis of the Insertion/Deletion Polymorphism of Angiotension Converting Enzyme Gene in Acute Coronary Syn-drome]. Chinese Journal of Cadiovasology 2000, 5:67-9.

10. Di Pasquale P, Cannizzaro S, Scalzo S, Maringhini G, Pipitone F, Fasullo S, Giubilato A, Ganci F, Vitale G, Sarullo FM, Paterna S: Cardiovascular effects of I/D angiotensin-converting enzyme gene polymorphism in healthy subjects. Findings after follow-up of six years. Acta Cardiol 2005, 60:427-35.

II. Lanfear DE, Jones PG, Marsh S, Cresci S, Spertus JA, McLeod HL: Connexin 37 (GJA4) genotype predicts survival after an acute coronary syndrome. Am Heart J 2007, 154:56I-6.

12. Wang Zhilu, Zhao Yongqing, He Jinchun, Yang Bingwu, Dai Ruijun, Peng Haiping, Liao Joshua D: [Prediction of the risk of acute coronary syndrome from polymorphisms in candidate genes]. Clin Cardiol (China) 2007, 23:8I 9-821.

13. Ciftçi C, Melil S, Cebi Y, Ersöz M, Caçatay P, Kiliçgedik M, Duman BS: Association of endothelial nitric oxide synthase promoter region (T-786C) gene polymorphism with acute coronary syndrome and coronary heart disease. Lipids Health Dis 2008, 7:5.

14. Li Yong, Zhu Tie-bing, Wang Lin-lin, Yang Zhi-jian, Fan Le-ming, Cao Ke-jiang: [Relationship between G894T polymorphism of endothelial nitric oxide synthase gene and acute coronary syndrome]. Acta Univ Med Nanjing 2007, 27:789-92.

15. Davies RL, Grosse VA, Kucherlapati R, Bothwell M: Genetic analysis of epidermal growth factor action: assignment of human epidermal growth factor receptor gene to chromosome 7 . Proc Natl Acad Sci USA 1980, 77:4I 88-92.

16. Haley J, Whittle N, Bennet P, Kinchington D, Ullrich A, Waterfield M: The human EGF receptor gene: Structure of the $110 \mathrm{~kb}$ locus and identification of sequences regulating its transcription. Oncogene Res 1987, I:375-96.

17. Moriai T, Kobrin MS, Korc M: Cloning of a variant epidermal growth factor receptor. Biochem Biophys Res Commun 1993, i $91: 1034-9$

18. Moriai T, Kobrin MS, Hope C, Speck L, Korc M: A variant epidermal growth factor receptor exhibits altered type a transforming growth factor binding and transmembrane signaling. Proc Natl Acad Sci USA 1994, 91: 102 I7-2I.

19. Gebhardt F, Zanker KS, Brandt B: Modulation of epidermal growthfactor receptor gene transcription by a polymorphic dinucleotide repeat in intron I. J Biol Chem 1999, 274: I3176-80.

20. Buerger H, Gebhardt F, Schmidt H, Beckmann A, Hutmacher K, Simon R, Lelle R, Boecker W, Brandt B: Length and loss of heterozygosity of an intron I polymorphic sequence of EGFR is related to cytogenetic alterations and epithelial growth factor receptor expression. Cancer Res 2000, 60:854-7.

21. Zhang W, Weissfeld JL, Romkes M, Land SR, Grandis JR, Siegfried JM: Association of the EGFR intron I CA repeat length with lung cancer risk. Mol Carcinog 2007, 46:372-80.

22. Brandt B, Hermann S, Straif K, Tidow N, Buerger $H$, Chang-Claude J: Modification of breast cancer risk in young women by a polymorphic sequence in the EGFR gene. Cancer Res 2004, 64:7-12.

23. Hsieh YY, Chang CC, Tsai FJ, Lin CC, Tsai CH: T homozygote and allele of epidermal growth factor receptor 2073 gene polymorphism are associated with higher susceptibility to endometriosis and leiomyomas. Fertil Steril 2005, 83:796-9.

24. Zhang W, Park DJ, Lu B, Yang DY, Gordon M, Groshen S, Yun J, Press OA, Vallböhmer D, Rhodes K, Lenz H]: Epidermal growth factor receptor gene polymorphisms predict pelvic recurrence in patients with rectal cancer treated with chemoradiation. Clin Cancer Res 2005, I I:600-5. 
25. Bandrés E, Barricarte R, Cantero C, Honorato B, Malumbres R, Zárate R, Alcalde J, García-Foncillas J: Epidermal growth factor receptor (EGFR) polymorphisms and survival in head and neck cancer patients. Oral Oncology 2007, 43:7| 3-9.

26. Wang WS, Chen PM, Chiou TJ, Liu JH, Lin JK, Lin TC, Wang HS, Su $Y$ : Epidermal growth factor receptor $R 497 \mathrm{~K}$ polymorphism is a favorable prognostic factor for patients with colorectal carcinoma. Clin Cancer Res 2007, 13:3597-604.

27. Prenzel N, Fischer OM, Streit S, Hart S, Ullrich A: The EGF receptor family as a central element for cellular signal transduction and diversification. Endocr Relat Cancer 200I, 8: I I-3I.

28. Kalmes A, Daum G, Clowes AW: EGFR transactivation in the regulation of SMC function. Ann N Y Acad Sci 200I, 947:42-54.

29. Berk BC: Vascular smooth muscle growth: autocrine growth mechanisms. Physiol Rev 200I, 81:999-1030.

30. Tamura R, Miyagawa J, Nishida M, Kihara S, Sasada R, Igarashi K, Nakata A, Yamamori K, Kameda-Takemura K, Yamashita S, Matsuzawa Y: Immunohistochemical localization of betacellulin, a member of epidermal growth factor family, in atherosclerotic plaques of human aorta. Atherosclerosis 200I, I55:4I3-23.

31. Nanney LB, Stoscheck CM, King LE: Characterization of binding and receptors for epidermal growth factor in smooth muscle. Cell Tissue Res 1988, 254:|25-32.

32. Tomita M, Hirata Y, Uchihashi M, Fujita T: Characterization of epidermal growth factor receptors in cultured vascular smooth muscle cells of rat aorta. Endocrinol Jpn 1986, 33: I77-84.

33. Ross R: Atherosclerosis: an inflammatory disease. New Engl J Med 1999, 340: II5-26.

34. Liu W, Innocenti F, Chen P, Das S, Cook EH, Ratain MJ: Interethnic difference in the allelic distribution of human epidermal growth factor receptor intron I polymorphism. Clin Cancer Res 2003, 9: 1009-12.

35. Araújo A, Ribeiro R, Azevedo I, Coelho A, Soares M, Sousa B, Pinto D, Lopes C, Medeiros R, Scagliotti GV: Genetic polymorphisms of the epidermal growth factor and related receptor in nonsmall cell lung cancer - a review of the literature. Oncologist 2007, I 2:20I-10.

36. Mclnerney JM, Wilson MA, Strand KJ, Chrysogelos SA: A strong intronic enhancer element of the EGFR gene is preferentially active in high EGFR expressing breast cancer cells. J Cell Biochem 200I, 80:538-549.

37. Schlessinger J: Cell signaling by receptor tyrosine kinases. Cell 2000, I03:21I-225.

38. Jorissen RN, Walker F, Pouliot N, Garrett TP, Ward CW, Burgess AW: EGF receptor: mechanisms of activation and signalling. Exp Cell Res 2003, 284:3I-53.

39. Moghal N, Sternberg PW: Multiple positive and negative regulators of signaling by the EGF-receptor. Curr Opin Cell Biol 1999 , II:190-196.

40. Lamb DJ, Modjtahedi H, Plant NJ, Ferns GA: EGF mediates monocyte chemotaxis and macrophage proliferation and EGF receptor is expressed in atherosclerotic plaques. Atherosclerosis 2004, 176:21-6.

41. Chansel D, Ciroldi M, Vandermeersch S, Jackson LF, Gomez AM, Henrion D, Lee DC, Coffman TM, Richard S, Dussaule JC, Tharaux PL: Heparin binding EGF is necessary for vasospastic response to endothelin. FASEB J 2006, 20:1936-8.

42. Wang X, Saito J, Ishida T, Munakata M: Polymorphism of egfr intron $I$ is associated with susceptibility and severity of asthma. J Asthma 2006, 43:7II-5.

43. Martin K, Radlmayr M, Borchers R, Heinzlmann M, Folwaczny C: Candidate genes colocalized to linkage regions in inflammatory bowel disease. Digestion 2002, 66:121-6.

44. Alpert JS, Thygesen K, Antman E, Bassand JP: Myocardial infarction redefined - a consensus document of The Joint European Society of Cardiology/American College of Cardiology committee for the redefinition of myocardial infarction. J Am Coll Cardiol 2000, 36:959-69.

45. Li Y, Wei YS, Wang M, Zhang PA, Jiang XJ, Huang CX: Association between the Ser I 28Arg variant of the E-selectin and risk of coronary artery disease in the central China. Int J Cardiol 2005, 103:33-6.

\section{Pre-publication history}

The pre-publication history for this paper can be accessed here:

http://www.biomedcentral.com/1471-2350/9/74/prepub
Publish with Biomed Central and every scientist can read your work free of charge

"BioMed Central will be the most significant development for disseminating the results of biomedical research in our lifetime. "

Sir Paul Nurse, Cancer Research UK

Your research papers will be:

- available free of charge to the entire biomedical community

- peer reviewed and published immediately upon acceptance

- cited in PubMed and archived on PubMed Central

- yours - you keep the copyright
BioMedcentral 